\title{
The Status Quo and Improvement Methods of College Physical Education Evaluation
}

\section{Wenhua Li}

Sichuan University of Arts and Science Dazhou, Sichuan Province 635000

\begin{abstract}
In the process of college physical education, teaching evaluation is one of the very important teaching tasks. Through a scientific and complete teaching evaluation system, the physical education process can be optimized to a certain extent, and the effective realization of physical education goals can be promoted to improve the college The quality and efficiency of physical education. This article first analyzes the status quo of college physical education evaluation, and then proposes some optimization and improvement measures for the problems found, hoping to improve the college physical education evaluation system and enhance the comprehensive ability of students.
\end{abstract}

Keywords: College Physical Education; Teaching Evaluation; Status Quo; Improvement Methods

Physical education in colleges and universities is an important teaching subject to realize the concept of quality education, and effective teaching evaluation is very necessary to truly promote the overall development of students' moral, intellectual, physical, and beauty. However, in actual teaching, the evaluation of physical education in colleges and universities still focuses on the training of students' professional ability, and does not pay attention to other abilities of students. Therefore, there are many problems in the overall teaching evaluation system that need to be improved and resolved. Based on many years of college physical education teaching experience, the author makes a detailed discussion on the status quo and improvement methods of college physical education evaluation based on actual teaching conditions, aiming to build a better physical learning environment for college students and comprehensively improve their comprehensive quality .

\section{The status quo of the development of teaching evaluation in college physical education}

\subsection{The subject of physical education evaluation is too single}

Judging from the current situation of physical education in colleges and universities, teaching evaluation still has the phenomenon of a single and one-sided evaluation subject. The main manifestation is that students are ignored as the subject of physical education. Most teaching evaluation activities are carried out around teachers, and the evaluation content is basically based on The professional sports abilities of students are the main ones, and few include judgments on other abilities of students. Under this kind of environment, students cannot understand their own comprehensive situation well, which makes the enthusiasm of physical education not high, and it is very easy for students to have coping psychology, which greatly affects the comprehensive development of students.

\subsection{The method of physical education evaluation is not reasonable enough}

Nowadays, the evaluation method of physical education teaching in colleges and universities in our country is still based on sports testing, and the testing standards are very uniform. The time period for testing is only the end of each semester. The testing time, testing standards and testing content are all unreasonable. The main reason is that it does not fully consider the individual differences of students, pays too much attention to test results, neglects the judgment of Copyright (C) 2020 Wenhua Li

doi: 10.18282/le.v9i7.1489

This is an open-access article distributed under the terms of the Creative Commons Attribution Non-Commercial License

(http://creativecommons.org/licenses/by-nc/4.0/), which permits unrestricted non-commercial use, distribution, and reproduction in any medium, provided the original work is properly cited. 
students' daily behavior, and lacks in guiding students to form good sports habits, which is not conducive to the further realization of physical education goals. Greatly reduces the effectiveness of college physical education.

\subsection{The goal of physical education evaluation is not clear enough}

Physical education in colleges and universities is based on the concept of quality education. The main teaching goal is to improve Xu Sheng's comprehensive ability and develop students' physical potential. Therefore, in the process of physical education evaluation, achieving the educational goal should be the main criterion. However, most colleges and universities still use the traditional teaching model in physical education. The pursuit of good sports performance in the evaluation of physical education does not promote the establishment of correct sports concepts for students. Under such teaching evaluation goals, teachers can easily go too far. The pursuit of sports performance, while ignoring the differences between individual students, has caused some students to weariness of physical education and lose their enthusiasm for participating in sports.

\section{Improved methods of college physical education teaching evaluation}

\subsection{Appropriately expand the main body of teaching evaluation}

With the continuous advancement of the new curriculum teaching reform, the traditional teacher-oriented teaching evaluation method is no longer suitable for the current development of college physical education. Therefore, the college physical education evaluation system should appropriately expand the scope of teaching evaluation and strengthen students' The main role. First of all, abandon the traditional teaching evaluation concept, establish the basis of teacher evaluation, so that students can also participate in the evaluation work, and give full play to students' subjective initiative in teaching. Secondly, encourage students to evaluate the teaching work of teachers, and strengthen student self-evaluation and mutual evaluation among students, so as to build a good physical education evaluation system and further enhance the effectiveness of physical education. Finally, the school itself should also participate in the evaluation of college physical education, looking at the problem from the overall teaching, and comprehensively controlling the entire college physical education activities, so as to promote the evaluation of college physical education to be carried out in a more orderly manner.

\subsection{Continuously optimize the evaluation method of physical education}

Traditional physical education evaluation methods are only used to distinguish and appraise students simply and crudely based on the results of physical education evaluations. They cannot accurately reflect students' physical use and are not conducive to accomplishing physical education goals. In order to improve this situation, teachers and related Physical education researchers need to continuously optimize the evaluation methods of physical education. First, change the traditional single evaluation concept, learn and understand the new teaching evaluation concept, and continuously improve the teaching evaluation system through teaching practice. Secondly, teachers should effectively clarify the content of physical education evaluation, starting from improving students' comprehensive literacy, focusing on the assessment of students' teaching practice, so as to better detect the actual situation of students so that teachers can follow up on the teaching content in a timely manner and improve colleges The effectiveness of physical education. Finally, attach importance to the assessment of students' Heisei performance, guide students to form healthy exercise habits for lifelong sports, and ensure the guiding role of physical education evaluation in teaching.

\subsection{Further clarify the evaluation objectives of physical education}

First of all, in the process of implementing teaching evaluation, teachers should combine the characteristics of physical education and comprehensively evaluate students from various aspects of student performance. They cannot simply judge students based on their physical performance. Secondly, teachers need to have a comprehensive understanding of the actual situation of students, comprehensively evaluate students in terms of physical fitness, exercise habits, sports awareness, and sports hobbies, and make more personalized evaluations of students based on actual test results, so as to keep each student's physical education The enthusiasm for sports. Finally, teachers should continue to instill active sports concepts into students in daily teaching, make students aware of the importance of physical exercise to their own development, and improve the effectiveness of college physical education. 


\section{Concluding remarks}

From the actual teaching situation, the evaluation of physical education in colleges and universities is of great significance to improving the effectiveness of physical education in colleges and universities. Therefore, schools and teachers should strengthen the importance of physical education, change the traditional single evaluation method, and pay attention to the daily life of students. The evaluation of behavior and sports awareness is used to improve the physical education evaluation system, and to better play the role of physical education evaluation in education and teaching, thereby improving the quality of college physical education and promoting the comprehensive quality of college students.

\section{References}

1. Li Zhenyu. The status quo and improvement methods of college physical education teaching evaluation [J]. Journal of Jiamusi Vocational College, 2018, 000(005): P.347-347.

2. Jixiang, Li Weidong, Zhou Jianlong. The status quo and improvement methods of college physical education teaching evaluation [J]. Curriculum Education Research: Study on Learning Method and Teaching Method, 2018, 000(017):245-245.

3. Huang Changguang. On the status quo and improvement methods of college physical education evaluation[J]. Sports Fashion, 2019, 000(010): P.149-149. 